\title{
The Analysis of Economy and Gas Emission for Alternative Energy
}

\section{Technology}

\author{
Yao Gang ${ }^{1}$, Zheng Fangpeng ${ }^{1}$, Zeng Ming $^{2}$,Wang Xin ${ }^{2}$, He Kelei $^{2^{*}}$ \\ (1 Guizhou Power Grid Corporation,Guiyang,Guizhou,China; 2 School of Economics and \\ Management, North China Electric Power University, Beijing 102206, China)
}

\begin{abstract}
Keywords: Alternative energy technology, economic analysis, gas emission reduction, energy efficiency

Abstract: The economic analysis model is structured by calculating the price to get break-even points of all programs; Second, considering energy consumption and emissions of each kind of technology, the emission reduction calculation model and energy efficiency analysis model are established; Finally, the empirical analysis is carried out. Results show that the proposed models could effectively calculate the economic and environmental profits as well as energy efficiency of each Alternative Energy programs, which could offer decision-making assistance for the government to proceed with the Alternative Energy programs and promote the development of low carbon.
\end{abstract}

\section{Introduction}

In recent years, the phenomenon of air pollution is growing in China. Large-scale, long periods fog and haze damages to the environment seriously, which brings great harm to people's health. The key to control air pollution is to reduce the proportion of coal consumption. So it will effectively increase the proportion of energy in the final energy consumption to carry out the alternative energy strategy "electricity instead of coal, electricity instead of oil, electricity from afar". Therefore, it's necessary to carry out economic analysis for each alternative energy technology and calculate emission reduction benefits to provide decision support, and promote the smooth implementation of alternative energy work.

From the perspective of current domestic and international researches, they focus on the hardware equipment analysis of single alternative energy technology and investment cost analysis, etc, and there are still gaps in the economy and reduction benefit analysis of major alternative energy technology. Currently, there has no literature constructing the model of calculating economic and environmental benefits of various alternative energy programs and analyzing energy efficiency. Therefore, firstly, this paper constructs a economic analysis model by the conversion price to get the break-even point of electricity price to analyze the economic benefits of various alternative energy programs; Secondly, emission reduction model and energy efficiency model of alternative energy technology are established, and then the environmental benefits and energy efficiency of each kind of technology are compared and analyzed; Finally, the empirical analysis is carried out based on the models above. According to market research data, the economic and environmental benefits and energy efficiency of each alternative energy program are calculated and the feasibility of program implementation is analyzed to provide a basis for government decision-making. 


\section{The construction of economic analysis model of alternative energy technology}

\section{Electricity replacing coal}

Provided the rated thermal power of coal products is $a \mathrm{kcal} / \mathrm{h}$, the coal consumption is $\mathrm{b} \mathrm{kg} / \mathrm{h}$, the conversion efficiency of thermal energy units is $1 \mathrm{~kW}=860 \mathrm{kcal} / \mathrm{h}$, the thermal efficiency of appliances is $c$, the thermal efficiency of coal products is $e$, the coal price is $d$ yuan $/ \mathrm{kg}$, the electricity price is $f$ yuan/kWh, the power of electrical appliances is $g \mathrm{~kW}$, the alternative conversion price of electrical appliances is:

$$
p_{1}=\frac{b c d \cdot 860}{a} \text {. }
$$

The break-even point of coal price is:

$$
p_{2}=\frac{f a}{b c \cdot 860} \text {. }
$$

That is according to the current coal price, when the electricity price is $p_{1}$ yuan $/ \mathrm{kWh}$, for users the electricity cost is equal to the cost using coal. On the other hand, according to the current electricity price, when the coal price is $p_{2}$ yuan $/ \mathrm{kWh}$, for users the electricity cost is equal to the cost using coal.

\section{Electricity replacing oil}

(1) Electric vehicles

Provided the power of electric vehicles is $h \mathrm{kWh} / \mathrm{km}$, the electricity price is $f$ yuan $/ \mathrm{kWh}$, the efficiency of electric vehicles is $i$, the fuel consumption of ordinary fuel vehicles is $j \mathrm{~L} / \mathrm{km}$, the efficiency is $k$, the oil price is $l$ yuan/L, the acquisition cost of electric vehicles is 250 thousand, the service life of electric vehicles is 400 thousand $\mathrm{km}$, and the purchase cost of fuel vehicles is 100 thousand, the conversion electricity price of electric vehicles is:

$$
p_{3}=\frac{i j l-0.375}{k h} \text {. }
$$

The break-even point of oil price is:

$$
p_{4}=\frac{h f k+0.375}{i j}
$$

(2) Agriculture electric irrigation and electric furnace

Provided the power of electrical equipment is $m \mathrm{~kW}$, the electricity price is $f$ yuan $/ \mathrm{kWh}$, the efficiency of electrical equipment is $n$, the fuel equipment is $o \mathrm{~L} / \mathrm{h}$, the efficiency is $q$, and the oil price is $l$ yuan/L, the conversion electricity price is: 


$$
p_{5}=\frac{o n l}{q m} \text {. }
$$

The break-even point of oil price of traditional pumps is:

$$
p_{6}=\frac{m f q}{n o}
$$

\section{Model construction of emission reduction and energy efficiency of alternative energy technology}

\section{Analysis of emission reduction}

Provided the gas emission of generating side is $r \mathrm{~g} / \mathrm{kWh}$, the usage time of electrical appliance is $t$, the gas emission of alternative products is $u$ (electricity replacing coal, $\mathrm{g} / \mathrm{kg}$; electricity replacing oil, $\mathrm{g} / \mathrm{L}$ ), and the coal consumption or fuel consumption is $v$, the reduction of gas emission is:

$$
\sigma=|u v t-r g t|
$$

\section{Analysis of energy efficiency}

The calculation methods of the energy efficiency of electricity replacing coal and electric replacing oil are the same: Provided the power generation efficiency of generation side is $w$, the power consumption rate is $x$, the line loss is $y$, and the power efficiency of electrical appliances is $z$, the energy efficiency of electrical appliances is:

$$
\pi=w x y z \text {. }
$$

Under normal circumstances, the alternative technology is primary energy. The energy utilization efficiency is set to $\theta$, so it can reflect the energy efficiency of alternative energy technologies by comparing the value of $\pi$ and $\theta$.

\section{Empirical analysis}

\section{Electricity replacing coal}

The economic indicators of the main technologies of electricity replacing coal are shown in table 1. The coal price is 519 yuan/t from the Bohai Sea thermal coal price index. The gas emission is $3.63 \mathrm{~g} / \mathrm{kWh}$ which is the mean of $\mathrm{NOx}, \mathrm{SO} 2$, and dust emission data from five power generation groups in 2012. The gas emission of coal products is $17 \mathrm{~kg} / \mathrm{t}$. According to the residential electricity price in Beijing, the electricity price is 0.4783 yuan $/ \mathrm{kWh}$. The highest energy conversion efficiency of generators is $42 \%$. The auxiliary power is $5 \%$. The line loss is $7 \%$. 
Table.1 Original data sheet

\begin{tabular}{|c|c|c|c|}
\hline Indicator & $\begin{array}{l}\text { Heat pump technology replacing } \\
\text { coal-fired heating }\end{array}$ & $\begin{array}{c}\text { Electric heating replacing } \\
\text { coal-fired heating }\end{array}$ & $\begin{array}{l}\text { Electric cooking replacing } \\
\text { coal-fired utensils }\end{array}$ \\
\hline \multicolumn{4}{|l|}{$\begin{array}{l}\text { Indicator } \\
\text { Program }\end{array}$} \\
\hline $\begin{array}{l}\text { Rated thermal } \\
\text { power of coal } \\
\text { products/(kg/h) }\end{array}$ & $10 \times 10^{4}$ & $10 \times 10^{4}$ & $27 \times 10^{4}$ \\
\hline $\begin{array}{l}\text { Coal } \\
\text { consumption/(kg/h) }\end{array}$ & 40 & 40 & 140 \\
\hline $\begin{array}{c}\text { Power efficiency of } \\
\text { appliances }(\%)\end{array}$ & 430 & 90 & 90 \\
\hline $\begin{array}{l}\text { The thermal } \\
\text { efficiency of coal } \\
\text { products }(\%)\end{array}$ & $60-80$ & $60-80$ & $60-70$ \\
\hline $\begin{array}{l}\text { Power of electrical } \\
\text { appliances } / \mathrm{kw}\end{array}$ & 75 & 10 & 2.1 \\
\hline $\begin{array}{l}\text { Usage time of } \\
\text { electrical } \\
\text { appliances/h }\end{array}$ & 900 & 900 & 360 \\
\hline
\end{tabular}

The data above are used in the model to get the economy, gas emission, and energy efficiency of various technologies for electricity replacing coal shown in table 2.

Table. 2 calculation results of various indexes for electricity replacing coal

\begin{tabular}{rcccc}
\hline $\begin{array}{c}\text { Alternative } \\
\text { technology }\end{array}$ & $\begin{array}{c}\text { Conversion } \\
\text { price/(yuan/kWh) }\end{array}$ & Break-even point/(yuan/t) & Energy efficiency & Gas emission/(kg/household) \\
\hline Heat pump & 0.77 & 330 & $159.6 \%$ & 367.51 \\
technology & 0.16 & 1545 & $41.1 \%$ & 579.33 \\
Electric heating & 0.21 & 1191 & $33.6 \%$ & 854.06 \\
\hline Electric cookers & & & \\
\hline
\end{tabular}

Seen from current three main technologies for electricity replacing coal, the economy of heat pump technology is the best, and its conversion price is higher than residential electricity price in most areas of our country, so it can be promoted among users without lowering electricity price. However, the economy of electric heating and electric cookers is poor, they can not be promoted until the price is reduced to 0.16 yuan $/ \mathrm{kWh}$ and 0.21 yuan $/ \mathrm{kWh}$ respectively. In terms of gas emission effectiveness and energy use, the gas reduction effect of these three technologies is very significant. The energy efficiency of heat pump technology is highest, but the energy efficiency of electric heating and electric cookers is low. In summary, the heat pump technology should be the focus to be promoted for electricity replacing coal in the future.

\section{Electricity replacing oil}

(1)Electric vehicle

Various economic indicators for electric vehicles replacing fuel vehicles are shown in table 3 and table 4. Set the driving distance in a year of electric vehicles and fuel vehicles is 20,000 kilometers. 
Table. 3 the economic indicators of electric vehicles

\begin{tabular}{cccc}
\hline Indicator & Power $(\mathrm{kWh} / \mathrm{km})$ & Electricity price/(yuan $/ \mathrm{kWh})$ & Power efficiency/\% \\
\hline Data & 0.15 & 0.4783 & 80 \\
\hline
\end{tabular}

Table.4 the economic indicators of fuel vehicles

\begin{tabular}{ccccc}
\hline Indicator & Power $/(\mathrm{L} / \mathrm{km})$ & Oil price $/$ yuan & Oil efficiency/\% & Gas emission/(kg/L) \\
\hline Data & 0.08 & 7.83 & 40 & 2.4 \\
\hline
\end{tabular}

(2)Electrical irrigation of agriculture

The economic indicators for electric irrigation replacing fuel pump irrigation are shown in table 5 and table 6.

Table. 5 the economic indicators of electric irrigation

\begin{tabular}{cccc}
\hline Indicator & Power/(kW) & Electricity price/(yuan $/ \mathrm{kWh})$ & Power efficiency/\% \\
\hline Data & 15 & 0.4783 & 70 \\
\hline
\end{tabular}

Table. 6 the economic indicators of fuel pump irrigation

\begin{tabular}{ccccc}
\hline Indicator & Power $/(\mathrm{L} / \mathrm{km})$ & Oil price/yuan & Oil efficiency/\% & Gas emission $/(\mathrm{kg} / \mathrm{L})$ \\
\hline Data & 5.12 & 7.94 & 90 & 2.0 \\
\hline
\end{tabular}

\section{Economic measure}

According to the data of electric vehicles and electric irrigation of agriculture, the economy and gas mitigation benefits of these two alternative energy technologies can be obtained shown in table 7.

Table.7 the calculation results of various alternative energy technologies for electricity replacing oil

\begin{tabular}{ccccc}
\hline $\begin{array}{c}\text { Alternative } \\
\text { technology }\end{array}$ & $\begin{array}{c}\text { Conversion } \\
\text { price/(yuan/kWh) }\end{array}$ & $\begin{array}{c}\text { Break-even } \\
\text { point/(yuan/L) }\end{array}$ & Energy efficiency & $\begin{array}{c}\text { Gas emission } \\
\text { reduction/(kg/household) }\end{array}$ \\
\hline $\begin{array}{c}\text { Electric } \\
\text { vehicle }\end{array}$ & 1.05 & 6.3 & $29.6 \%$ & 367.51 \\
$\begin{array}{c}\text { Electric } \\
\text { irrigation of } \\
\text { agriculture }\end{array}$ & 2.1 & 1.77 & $26.0 \%$ & 737.8 \\
\hline
\end{tabular}

According to the calculation results, the economy of electric vehicles and electric irrigation of agriculture is pretty high, their energy efficiency is acceptable and the energy saving benefits are good, so they should be vigorously promoted.

\section{Conclusion}

Widely carrying out alternative energy work can effectively promote energy conservation and reduce haze harm. Therefore, it has become an important domestic researching field.

This paper constructs the economic analysis model of alternative energy technologies. The economy, gas mitigation benefits and energy efficiency are analyzed by calculating conversion price 
and break-even point for each alternative energy technology. The results show that heat pump technology, electric irrigation of agriculture and electric vehicle has high economy and good gas mitigation benefits, which should be vigorously promoted in the future as alternative energy programs.

\section{References}

[1] Shi D. Analysis of China's renewable energy development under the current economic and technical circumstances. China \& World Economy 2009; 17(2):94-109.

[2] Ma H, Oxley L, Gibson J, Li W. A survey of China's renewable energy economy. Renewable \& Sustainable Energy Reviews 2010; 14(1):438-45

[3] Liu T, Xu G, Cai P, Tian L, Huang Q. Development of forecast of renewable energy power generation in China and its influence on the GHG control strategy of the country. Renewable Energy 2011; 36(4):1284-92.

[4] Zhao ZY, Zuo J, Fan LL, Zillante G. Impacts of renewable energy regulations on the structure of power generation in China - A critical analysis. Renewable Energy 2011; 36(1):24-30.

[5] Cherni JA, Kentish J. Renewable energy policy and electricity market reforms in China. Energy Policy 2007; 35(7): 3616-29.

[6] Gao X, Jin B, Li B, Yang K, Zhang H, Fan B. Study on renewable energy development and policy in China. Proceeding of the International Conference on Energy, Environment and Development (ECEED 2010), Kuala Lumpur, Malaysia, 8-9 December; 2010.

[7] Zhao X, Liu X, Liu P, Feng T. The mechanism and policy on the electricity price of renewable energy in China. Renewable \& Sustainable Energy Reviews 2011; 15(9):4302-9.

[8] Wang Q. Effective policies for renewable energy - the example of China's wind power - lessons for China's photovoltaic power. Renewable \& sustainable energy reviews 2010; 14(2):702-12.

[9] China National People's Congress (NPC). Renewable Energy Law; February 2005. 